\title{
The Relationship between Organizational Ethical Climate and Organizational Trust in Palestinian Ministries: An Empirical Approach
}

\author{
Tariq T. Jarrar (corresponding author) \\ School of Management \\ Universiti Sains Malaysia (USM) \\ E-mail: tariq.jarrar@gmail.com \\ Penang - Malaysia \\ Dr. Hazril Izwar Ibrahim \\ School of Management \\ Universiti Sains Malaysia (USM) \\ E-mail: hazrilizwar@usm.my \\ Penang - Malaysia
}

Received: Jan. 13, $2021 \quad$ Accepted: Feb. 7, $2021 \quad$ Online published: Feb. 25, 2021

doi:10.5296/jpag.v11i1.18197ＵRL: https://doi.org/10.5296/jpag.v11i1.18197

\begin{abstract}
The purpose of this article is to investigate the relationship between organizational ethical climate and organizational trust in Palestinian public ministries by applying the Victor and Cullen's (1988) framework. For this purpose, the study utilizes a sample of 178 respondents of executive-level employees in which primary data collection is conducted using survey instrument and PLS-SEM for data analysis. The study proposes that a positive relationship between ethical climate types (Caring, Independence, Rules, Law and Codes) and organizational trust, and negative relationship between (Instrumental climate) and organizational trust are all highly important for Palestinian ministries to provide trust and create positive outcome in the workplace.
\end{abstract}

Keywords: organizational ethical climate, organizational trust, social exchange theory, public sector 


\section{Introduction}

The role of government in countries around the world has evolved dramatically due to significant technological, economic, social, and political changes. Thus, ministries are expected to extend more reliable and credible services that can meet or exceed citizens' needs. Organizational climate is a multidimensional construct that includes a wide range of individual estimation of work climate; climate is an organizational framework that refers to values, practice, traditions, procedures, and their effects on the behavior of employees in the organization (Al Shobaki et al., 2018). Organizational trust is important for both supervisors and employees; moreover, trust forms the foundation of compatible and fruitful relationships and effective cooperation within the organization (Tschannen-Moran \& Hoy, 1998) in order to improve employee performance and increase the organization's level of effectiveness.

The modality of the relationship between managers and employees is often studied through Social Exchange Theory. This is one of the most significant relationships for the employee and the most significant predictors of outcomes in the work place (Gerstner \& Day, 1997). Social exchange relationships entail unspecified commitments in which the parties implicated reciprocate effort toward one another overtime, whereas economic exchanges confirm the financial and tangible sides of exchange relationships (Lilly et al., 2016). Put differently, organizational trust includes expectations of reciprocity, such that individuals engage in trusting behavior because they expect others to do the same (Korsgaard et al., 2015)

In the context of Palestine, insufficient empirical studies exist on organizational ethical climate and organizational trust in the ministries. The study therefore explores the reality of the organizational ethical climate and its impact on the organizational trust in the ministries in Palestine. This study is important as it represents a crucial step in the development of public organizations in Palestine.

Over the last two decades, public organizations and ministries in Palestine have vastly grown (Al-Habil \& El-Ghazali, 2017a). Public sector development in Palestine is singular and challenging due to the fact that this system, in comparison with other public sectors in the area, has been built in an incomplete sovereign state, and because Palestine is not an independent country.

Indeed, since the arrival of the Palestinian National Authority (PNA) in 1994, Palestinian ministries have been suffering from many of the administrative problems cited in the report of the General Supervisory Authority, including the waste of public funds, lack of organizational structures, job inflation, alarming unemployment, overlapping powers, and other areas. These problems have hindered the performance of these ministries (Al-Habil \& El-Ghazali, 2017b). These structural defects in the Palestinian public sector are not compatible with relevant public policy.

Palestinian ministries have also been suffering from many of the administrative problems including the lack of organizational structure, and due to the gap in the literature, this study seeks to examine the relationship between organizational ethical climate and organizational trust. Ministries in Palestine are a good example of organizations that require a good 
organizational ethical climate in order to improve organizational trust, so that they can carry out their duties to fulfill their organization objectives. Due to the scarcity of research related to organizational ethical climate and its' influence on organizational trust, this study seeks to enrich the understanding on organizational trust by examining their relationship with the organizational ethical climate as independent variable. Organizational trust will thus bring a new insight as a dependent variable, focusing the relation between these variables.

Therefore, it is vital to examine the relationship between ethical climate and organizational trust in Palestinian context. This study explores which ethical climate types have a positive or negative relationship with the organizational trust in the ministries in Palestine, applying the Victor and Cullen's framework of ethical climate. The following sections discuss literature review, methodology, data analysis, results, discussion, limitation and conclusion.

Research Objectives: By identifying problem and asking research questions, the research objectives are set to investigate the relationship between organizational ethical climate and organizational trust.

\section{Literature Study}

Organizational ethical climate is an important aspect of the organization that mirrors the shared perceptions held by employees related to the norms, practices, policies and procedures in the organization and whether the culture of the organization is right or wrong (Nedkovski et al., 2017). Researchers thus emphasize the significance of studying the ethical work climate in organizations because of its importance affecting employees' attitudes and behavior (Lopez \& McMillan Capehart, 2009).

Studies have indicated that negative ethical climates result in unethical behaviors; while positive ethical climates are negatively correlated with unethical behaviors, (Smith et al., 2009)(Wimbush \& Shepard, 1994). Additionally, managers operating in a positive ethical climate perceive a positive cooperation between success and ethical behavior, while managers operating in a negative ethical climate perceive a negative cooperation between success and ethical behavior (Deshpande, 1996).

An ethical work climate benefits the organization in several ways. Ethical organizations are perceived to have better reputations. An ethical climate can also motivate its employees to work honestly, produce better services, which improves organizational performance (Prottas, 2013). In addition, an ethical work climate creates a contributory work environment, which increases employee satisfaction, enhances work attitudes, and helps organization to maintain its human resources value (Jaramillo et al., 2006)

According to Victor and Cullen (1988a), the different kinds of ethical climates existing in organizations can be found by looking at two specific criteria. The first, taken from the theory of cognitive moral development advanced by (Kohlberg, 1977), has three components: egoism, benevolence, and principle. The second dimension, derived from sociological theories on the roles of reference groups in organizations, concerns three loci of analysis: individual, local, and cosmopolitan (Victor \& Cullen, 1988b). Victor and Cullen, (1988b) combine the two dimensions and suggest the classification of ethical climates into nine theoretical types. In an 
empirical study, they use their ethical climate questionnaire (ECQ) to flesh out five of the nine ethical climates that can be found in groups, calling them: instrumental climate, which emphasizes the self-interest of individuals or small groups; caring climate, which valorizes the well-being of others at the individual or local level; independence climate, which stresses commitment to individuals' personal ethical attitudes; Rules climate, which gives primacy to an organization's policies and procedures and inculcates principled concern at the local level. Law and code climate is the assertion of responding according to the law and professional standards, a principled concern at the cosmopolitan level). The crossing of these two theoretical dimensions of ethical climate results in nine theoretical climate types (Wang \& Hsieh, 2013).

(Victor \& Cullen, 1988b) cross-classify the ethical criterion and locus of analysis dimensions, resulting in nine theoretical ethical climates as illustrated in Table 1.

Table 1. Theoretical Ethical Climate Types

\begin{tabular}{cccc}
\hline & Individual & Local & Cosmopolitan \\
\hline Egoism & Self interest & Company profit & Efficiency \\
Benevolence & Benevolence & Team interest & Social responsibility \\
Principle & Personal & $\begin{array}{c}\text { Company rules and } \\
\text { procedures }\end{array}$ & $\begin{array}{c}\text { Laws and professional } \\
\text { codes }\end{array}$ \\
\hline
\end{tabular}

Source: Victor and Cullen (1988)

There is no consensus among prominent authors on a single definition of individual or organizational trust. Trust has a long narrative of being critical for perception of interpersonal dynamics, which is a key function in organizational behavior and achievement (Rhee, 2010). Unless individuals and their organizations trust one another, then both might suffer because of costly retaliation and decreased organizational performance (Kramer \& Tyler, 1996). On the other hand, high standards of trust in the workplace can lead to improved levels of organizational commitment (Guinot et al., 2013).

Trust is commonly viewed as significant for successful organizational mission, and distrust is considered harmful for organizational conformity and conduct. For example, (Yiu \& Law, 2012) assumes that trust is current and is important for the reciprocity of familiarity within organizations and that this reciprocity is crucial if organizations are to survive. However, organizational leaders often answered defensively inquiries related to trust scales in their organizations, and their answers might prevent individual as well as organization from knowing (Nedkovski et al., 2017)). (A. Cohen, 2016) defines organizational trust as a psychological state comprised of the willingness to accept vulnerability based on positive expectations of organizations. (Sousa-Lima et al., 2013) indicate that trust building with organizations is the key element for developing a social exchange relationship. They propose 
in the study that trust is a central factor that enhances the organization's long-term success and survival, so trust is very important to facilitate the formation of work-related behavior. Organizational trust can also be included in these factors. It can be said that trust is the determinant of benevolent relationships and conformity between people. Trust is the "emotion of believing and engaging without fear and hesitation" (Dunn \& Schweitzer, 2005). Trust means that one side in a relationship is curtailed that the other side will not exploit his or her weakness (Duane \& O'Reilly, 2017), which entails expecting positive actions from other individuals (Jong\& Elfring, 2010). Trust is a human feeling reinforced and improved by mutual consideration and commitment, and is a concept based on sincerity and integrity in the most general feeling (Gülbahar, 2017). Organizational trust is important for both supervisors and employees; moreover, Trust forms the foundation of compatible and fruitful relationships and effective cooperation within the organization (Tschannen-Moran \& Hoy, 1998) in order to improve employee performance and increase the organization's level of effectiveness.

The hypotheses for this study are developed from the extensive literature review and the relationship between variables based on the proposed organizational ethical climate and organizational trust. Lilly et al., (2016) found that the ethical climate which evolves from these institutional sources can influence perceptions of trust, and (DeConinck, 2011) established that some features of the ethical work climate are directly related to organizational trust, whose prerequisites include organizational structure, culture, and leadership--three institutional sources of trust which comprise a system of formal procedures, values, and leadership to influence employee behavior (Bai et al., 2012).

Organizational ethical climate and organizational trust are linked to positive work outcomes that may benefit the organization, but a few studies examine the relationship between organizational ethical climate and organizational trust, although the top management in organizations should recognize the importance of organizational ethical climate for increasing organizational trust in this rapidly competitive world (Dickson et al., 2001). In the study by Whitener, Brodt, Korsgaard, \& Werner (1998) personality is a major requirement for forming trust, and honesty is one of the components of personality. Trustees share ability (using characteristics which enable one side influence over the other); benevolence (the willingness of the trustee to help the trustor); and integrity (the trustor's belief that the trustee conforms to appropriate principles). (Mayer \& Davis, 1999) indicate that the level of trust is an indication of the amount of risk people are willing to accept. Authors such a (Nedkovski et al., 2017), (Lilly et al. 2016) and (Kaptein, 2011) have argued that trust and ethics are intimately linked, and that preserving trust is the major driver of ethical behavior. (Whitener et al., 1998) were of the opinion that trust could happen outside the calculations of self-interest and underlie the benevolence dimension of an organizational climate.

From discussion above, the following hypotheses are formulated. See figure 1.

H1: There is a significant and positive relationship between Instrumental Climate (IC) and Organizational Trust (OT).

H2: There is a significant and positive relationship between Caring Climate (CC) and 
Organizational Trust (OT).

H3: There is a significant and positive relationship between Independence Climate (IC) and Organizational Trust (OT).

H4: There is a significant and positive relationship between Rules Climate (RC) and Organizational Trust (OT).

H5: There is a significant and positive relationship between Law and Codes Climate (LCC) and Organizational Trust (OT).

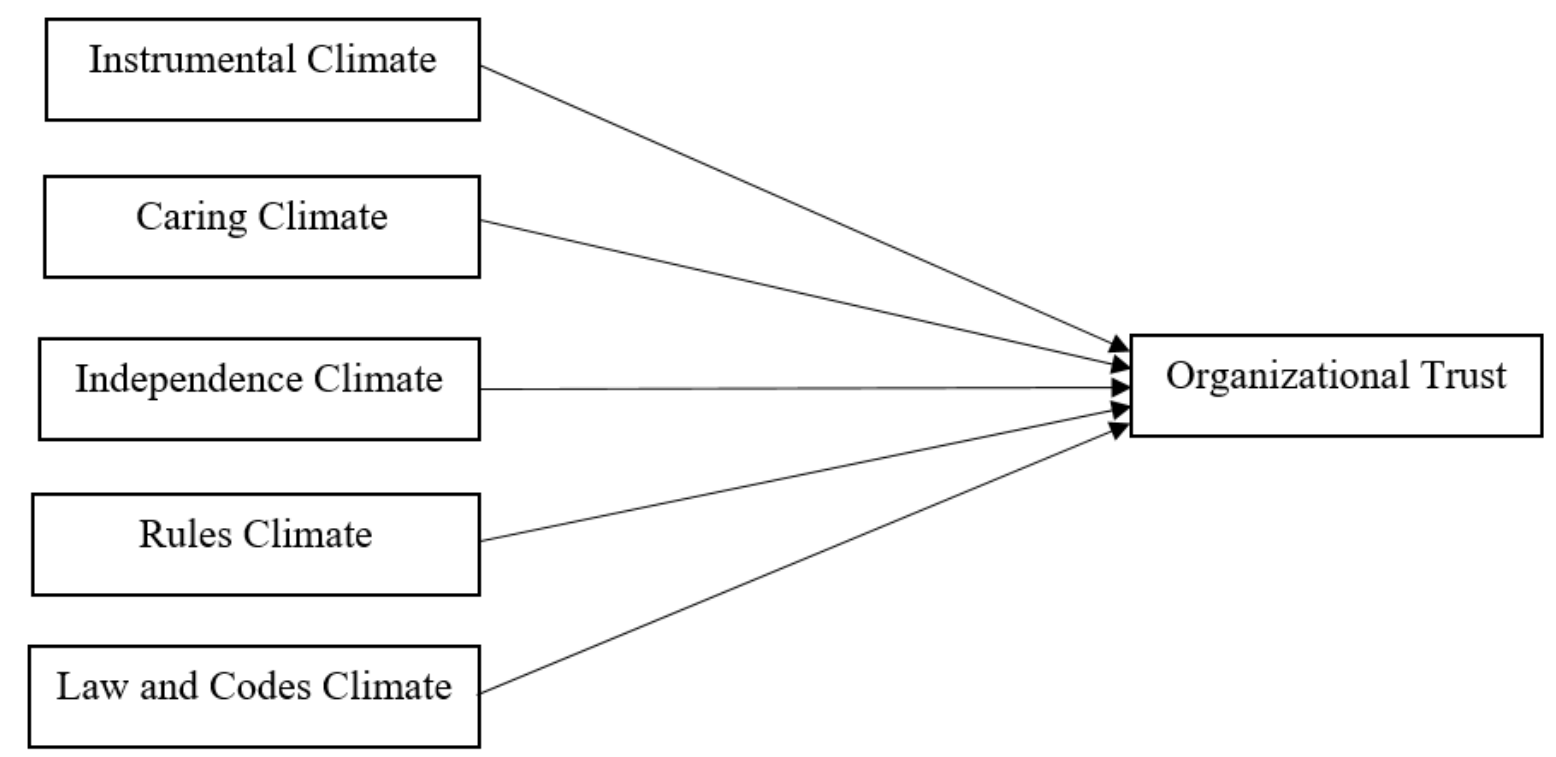

Figure 1. Conceptual Model and Hypotheses

\section{Method}

This study uses quantitative research methods. Data are collected from a sample working in 21 ministries in Palestine. The inclusion criteria are that the minimum qualification of a degree and have worked minimum of one year in the respective ministry. The questionnaire used in this study is prepared used a Likert scale. A total of 200 responses or $56 \%$ from 356 distributed questionnaire are successfully collected via drop and collect method, with 178 being the minimum responses targeted based on $\mathrm{G}^{*}$ Power, distributed with purposive sampling technique.

Out of 200 total responses, 126 respondents (63\%) are males and remaining 74 respondents are females (37\%). The majority of participants aged between 20-25 years old (11\%), 25-30 years' old (18.5\%), 30-35 years old (23.5\%), 35-40 (24.5\%), 40-45 years old (16\%), more than 45 years old $(6.5 \%)$. In terms of academic qualification, most of the respondent hold degrees $(86.5 \%)$, followed by master $(13.5 \%)$. The demographic profile $(24.5 \%)$ of the respondent is less than 5 years working experience, followed by 5-10 years (33\%), 10-15 years $(26.5 \%)$ and above 15 years of experience (16\%). In other words, majority of the respondents $(100 \%)$ have more than 1-year working experience. In terms of monthly salary, 


\section{Macrothink}

$80.5 \%$ of the respondents are earning more than ILS 3000 - less than ILS 5000 every month, followed by $19.5 \%$ earning more than ILS 5000 - Less than ILS 8000. Additionally, married employees represent the majority of the respondents $(69 \%)$ while the remaining are single employees $(31 \%)$. These serve as the input to the analysis of the current study which uses PLS-SEM analysis.

\section{Measures}

The questionnaire used in this study consists of four parts. The first part includes selection criteria of which ministry the participant is currently working in. The second part demographic profile of respondents: age, gender, marital status, level of education, length of service, and salary. The third part shows the organization's ethical climate as measured by the scale of (Victor \& Cullen, 1988b). Subscales are determined using a 5-point Likert scale on which $1=$ strongly disagree and $5=$ strongly agree. The number of items on these subscales varies, consisting of 4 for the rules and laws and codes subscale, 5 for the instrumental and independence scales, and 6 for the caring climate subscale. The fourth part is organizational trust that was measured using 4 items developed by (Mayer et al., 1995). All subscales are measured with a 5 -point Likert scale with $1=$ strongly disagree and $5=$ strongly agree. The organizational trust subscales have 4 items. Table 2 shows the demographic profile of the respondents. Means and standard deviation for all measures are shown in Table 3.

Table 2. Demographic Profile of the Respondents

\begin{tabular}{|c|c|c|c|}
\hline Profile & Description & Frequency & Percentage $(\%)$ \\
\hline \multirow[t]{6}{*}{ Age } & More than 20 - Less than 25 years old & 22 & 11 \\
\hline & More than 25 - Less than 30 years old & 37 & 18.5 \\
\hline & More than 30 - Less than 35 years old & 47 & 23.5 \\
\hline & More than 35 - Less than 40 years old & 49 & 24.5 \\
\hline & More than 40 - Less than 45 years old & 32 & 16 \\
\hline & More than 45 years old & 13 & 6.5 \\
\hline \multirow[t]{2}{*}{ Gender } & Male & 126 & 63 \\
\hline & Female & 74 & 37 \\
\hline Marital & Single & 62 & 31 \\
\hline Status & Married & 138 & 69 \\
\hline \multirow[t]{2}{*}{ Education } & Degree & 173 & 86.5 \\
\hline & Master & 27 & 13.5 \\
\hline \multirow[t]{4}{*}{ Experience } & More than 1 - Less than 5 years & 49 & 24.5 \\
\hline & More than 5 - Less than 10 years & 66 & 33 \\
\hline & More than 10 - Less than 15 years & 53 & 26.5 \\
\hline & More than 15 years & 32 & 16 \\
\hline \multirow[t]{2}{*}{ Salary } & More than ILS 3000 - Less than ILS 5000 & 161 & 80.5 \\
\hline & More than ILS 5000 - Less than ILS 8000 & 39 & 19.5 \\
\hline
\end{tabular}




\section{IIMacrothink

Table 3. Means and standard deviations

\begin{tabular}{|c|c|c|}
\hline Variable & Mean & Std. Deviation \\
\hline INSC1 & 3.04 & 1.058 \\
\hline INSC2 & 3.14 & 1.016 \\
\hline INSC3 & 2.94 & .949 \\
\hline INSC4 & 3.02 & 1.002 \\
\hline INSC5 & 3.06 & .986 \\
\hline $\mathrm{CC} 1$ & 3.44 & 1.106 \\
\hline $\mathrm{CC} 2$ & 3.29 & 1.049 \\
\hline $\mathrm{CC} 3$ & 3.37 & 1.053 \\
\hline $\mathrm{CC} 4$ & 3.45 & 1.083 \\
\hline $\mathrm{CC} 5$ & 3.44 & .894 \\
\hline CC6 & 3.08 & 1.067 \\
\hline INDC1 & 2.99 & .995 \\
\hline INDC2 & 3.13 & .910 \\
\hline INDC3 & 3.14 & .839 \\
\hline INDC4 & 3.12 & .903 \\
\hline $\mathrm{RC} 1$ & 3.13 & .835 \\
\hline $\mathrm{RC} 2$ & 3.20 & .800 \\
\hline $\mathrm{RC} 3$ & 3.23 & .859 \\
\hline $\mathrm{RC} 4$ & 3.30 & .851 \\
\hline LCC1 & 3.26 & .808 \\
\hline $\mathrm{LCC} 2$ & 3.18 & 1.123 \\
\hline $\mathrm{LCC} 3$ & 3.03 & 1.082 \\
\hline $\mathrm{LCC} 4$ & 2.73 & 1.112 \\
\hline OT1 & 3.38 & 1.000 \\
\hline OT2 & 3.31 & .974 \\
\hline OT3 & 3.28 & .972 \\
\hline OT4 & 3.38 & 1.010 \\
\hline
\end{tabular}

\section{Results}

Table 3 shows the means and standard deviation for the key variables in the study. Following Sekaran \& Bougie (2016), for items in the five-point scale, mean scores of equal or less than 2.99 were regarded as low, mean score ranging from 3 to 3.99 were regarded as moderate and means scores of 4 and higher were regarded as high. As demonstrated in statistical analysis, organizational trust has an R2 value of 0.578 , indication a substantial level of variance explained by (Cohen et al., 1983). An R2 of 0.578 indicates that $50.78 \%$ of variance in organizational trust can be explained by the five dimensions of independent variable (e.g. Instrumental Climate, Caring Climate, Independence Climate, Rules Climate, Law and Codes Climate).

Results from the bootstrapping analysis suggest that of the five hypothesized paths tested, one path is insignificant (i.e. Instrumental Climate - Organizational Trust) and the other four 
hypotheses are supported. Of these five, caring climate has the strongest effect on organizational trust $(\mathrm{t}=5.243, \mathrm{p}<0.01)$. The PLS output is shown in Table 4 that shows detailed result of path coefficient, standard errors and t-values for the direct effects between organizational ethical climate dimensions and organizational trust.

Table 4. Hypothesis Testing (Direct Effects between Organizational Ethical Climate and Organizational Trust)

\begin{tabular}{|c|c|c|c|c|c|c|c|}
\hline \# & Path & $\begin{array}{c}\text { Original } \\
\text { Sample }(\mathrm{O})\end{array}$ & $\begin{array}{c}\text { Sample } \\
\text { Mean (M) }\end{array}$ & $\begin{array}{l}\text { Std. Dev. } \\
\text { (STDEV) }\end{array}$ & $\begin{array}{l}\text { T Statistics } \\
\text { (O/STDEV) }\end{array}$ & $\begin{array}{c}\mathrm{P} \\
\text { Values }\end{array}$ & Result \\
\hline H1 & $\begin{array}{l}\text { Instrumental Climate -> } \\
\text { Organizational Trust }\end{array}$ & 0.069 & 0.069 & 0.060 & 1.162 & 0.123 & $\begin{array}{c}\text { Not } \\
\text { Supported }\end{array}$ \\
\hline $\mathrm{H} 2$ & $\begin{array}{l}\text { Caring Climate -> } \\
\text { Organizational Trust }\end{array}$ & 0.320 & 0.320 & 0.061 & 5.243 & 0.000 & \\
\hline H3 & $\begin{array}{l}\text { Independence Climate -> } \\
\text { Organizational Trust }\end{array}$ & 0.211 & 0.215 & 0.062 & 3.380 & 0.000 & Supported \\
\hline $\mathrm{H} 4$ & $\begin{array}{l}\text { Rules Climate } \\
\text { Organizational Trust }\end{array}$ & 0.265 & 0.263 & 0.066 & 4.013 & 0.000 & \\
\hline H5 & $\begin{array}{l}\text { Law \& Codes Climate -> } \\
\text { Organizational Trust }\end{array}$ & 0.133 & 0.135 & 0.052 & 2.559 & 0.005 & Supported \\
\hline
\end{tabular}

\section{Discussion}

The present study has 5 major hypotheses that measure the level of significance of direct relationship between the variables of organizational ethical climate and organizational trust. The results from the path coefficients attest that out of the 5 hypotheses, 4 are supported and 1 is not supported.

The first five hypotheses $\mathrm{H} 1, \mathrm{H} 2, \mathrm{H} 3, \mathrm{H} 4$ and $\mathrm{H} 5$ postulate that there is a significant and a positive relationship between all dimensions of organizational ethical climate (instrumental climate, caring climate, independence climate, rules climate and law and codes climate) and organizational trust.

The results reveal that the (instrumental climate) has insignificant relationship with the organizational trust. These findings are in line with the previous study undertaken in Saudi context (Alghamdi, 2018), hence not as expected. In addition to these constructs, the study notes an important relationship between the ethical climate (caring, independence, rules, laws and codes) and the level of trust found in an organization, a finding similar to that of earlier studies by (Deshpande, 1996; Simha \& Stachowicz-Stanusch, 2015; Lilly et al., 2016) As a conclusion, $\mathrm{H} 1$ is rejected and $\mathrm{H} 2, \mathrm{H} 3, \mathrm{H} 4$ and $\mathrm{H} 5$ are supported.

\section{Conclusion}

This article has examined the relationships among organizational ethical climate dimensions (instrumental climate, caring climate, independence climate, rules climate and law and codes climate) and organizational trust, perceived research on organizational ethical climate and organizational trust at the ministries in the West Bank of Palestine. This article represents new 
concepts and develops a better understanding on management practices in Palestine.

The proposed study model provides several essential results based on the analysis of the survey questionnaires distributed among employees at 21 Palestinian ministries. Analysis is executed by using PLS modeling to test the direct and indirect effects between the variables, and the findings are used to validate the proposed hypothesis.

This article uses Social Exchange Theory to examine relationship between ethical climate and organizational trust. The Results demonstrate how ethical climate relates to organizational trust and organizational performance. Out of four dimensions of caring climate, independence climate, rules climate and law and codes climate is significantly and positively contributed to organizational trust, while instrumental climate does not correlate with organizational trust.

There is a limitation to the present study that can be addressed in the future to make it more effective. This article is limited to the ministries in the West Bank in Palestine. The scope can be further expanded to public sector organizations to investigate and gain broader understanding on various approaches in managing employees in successful organization to avoid generalization and bias of results which consequently can further improve the quality of research.

This study gives implications towards employees at ministries in the public sector in the West Bank of Palestine, because its findings provide insight and a better understanding of the organizational ethical climate. Future studies should intend to discover new findings and contributions in different areas of organizational ethical climate and its dimension i.e. (instrumental climate, caring climate, independence climate, rules climate and law and codes climate) and organizational trust.

\section{Acknowledgments}

I would like to acknowledge AP Dr. Hazril Izwar Ibrahim at the School of Management at USM for his contribution in various facets of this article, especially his comments on the statistical analysis on the questionnaires.

\section{References}

Al-Habil, W. I., \& El-Ghazali, S. (2017a). The Impact of Political based Recruitment's Dimensions on the Quality of Governmental Services in Palestinian Public Ministries. https://doi.org/10.4172/2315-7844.1000208

Al-Habil, W. I., \& El-Ghazali, S. (2017b). The Impact of Political based Recruitment's Dimensions on the Quality of Governmental Services in Palestinian Public Ministries. https://doi.org/10.4172/2315-7844.1000208

Al Shobaki, M. J., Abu-Naser, S. S., Amuna, Y. M. A., \& Talla, S. A. El. (2018). The Level of Organizational Climate Prevailing In Palestinian Universities from the Perspective of Administrative Staff. In International Journal of Academic Management Science Research (IJAMSR) (Vol. 2, Issue 5). www.ijeais.org/ijamsr

Alghamdi, F. (2018). Investigating the Influence of Ethical Climate on Trust in Organization 
and Trust in Supervisor in Albaha Province, Saudi Arabia, Using Victor and Cullen's Framework. Journal of Service Science and Management, 11(04), 383-398. https://doi.org/10.4236/jssm.2018.114027

Bai, Y., Li, P. P., \& Xi, Y. (2012). The distinctive effects of dual-level leadership behaviors on employees' trust in leadership: An empirical study from China. Asia Pacific Journal of Management, 29(2), 213-237. https://doi.org/10.1007/s10490-011-9280-6

Cohen, A. (2016). Organizational Trust. In Fairness in the Workplace (pp. 51-66). Palgrave Macmillan UK. https://doi.org/10.1057/9781137524317_5

Cohen, S., Kamarck, T., \& Mermelstein, R. (1983). A global measure of perceived stress. Journal of Health and Social Behavior, 24(4), 385-396. https://doi.org/10.2307/2136404

DeConinck, J. B. (2011). The effects of ethical climate on organizational identification, supervisory trust, and turnover among salespeople. Journal of Business Research, 64(6), 617-624. https://doi.org/10.1016/j.jbusres.2010.06.014

Deshpande, S. P. (1996). Ethical climate and the link between success and ethical behavior: An empirical investigation of a non-profit organization. Journal of Business Ethics, 15(3), 315-320. https://doi.org/10.1007/BF00382957

Dickson, M. W., Smith, D. B., Grojean, M. W., \& Ehrhart, M. (2001). An organizational climate regarding ethics: The outcome of leader values and the practices that reflect them. Leadership Quarterly, 12(2), 197-217. https://doi.org/10.1016/S1048-9843(01)00069-8

Duane, A., \& O'Reilly, P. (2017). A conceptual stages-of-growth model for managing a social media business profile. The Irish Journal of Management, 36(2), 78-98. https://doi.org/10.1515/ijm-2017-0015

Dunn, J. R., \& Schweitzer, M. E. (2005). Feeling and Believing: The Influence of Emotion on Trust. https://doi.org/10.1037/0022-3514.88.5.736

Gerstner, C. R., \& Day, D. V. (1997). Meta-analytic review of leader-member exchange theory: Correlates and construct issues. Journal of Applied Psychology, 82(6), 827-844. https://doi.org/10.1037/0021-9010.82.6.827

Guinot, J., Chiva, R., \& Mallén, F. (2013). Organizational trust and performance: Is organizational learning capability a missing link? Journal of Management and Organization, 19(5), 559-582. https://doi.org/10.1017/jmo.2014.3

Gülbahar, B. (2017). The Relationship between Work Engagement and Organizational Trust: A Study of Elementary School Teachers in Turkey. Journal of Education and Training Studies, 5(2). https://doi.org/10.11114/jets.v5i2.2052

Jaramillo, F., Mulki, J. P., \& Solomon, P. (2006). The Role of Ethical Climate on Salesperson's Role Stress, Job Attitudes, Turnover Intention, and Job Performance. Journal of Personal Selling \& Sales Management, 26(3), 271-282. https://doi.org/10.2753/PSS0885-3134260302 
JONG, B. A. DE, \& ELFRING, T. (2010). HOW DOES TRUST AFFECT THE PERFORMANCE OF ONGOING TEAMS? THE MEDIATING ROLE OF REFLEXIVITY, MONITORING, AND EFFORT. In The Academy of Management Journal (Vol. 53, pp. 535-549). Academy of Management. https://doi.org/10.2307/25684335

Kaptein, M. (2011). From Inaction to External Whistleblowing: The Influence of the Ethical Culture of Organizations on Employee Responses to Observed Wrongdoing. Journal of Business Ethics, 98(3), 513-530. https://doi.org/10.1007/s10551-010-0591-1

Kohlberg, L., \& Hersh, R. H. (1977). Moral Development: A Review of the Theory. In Theory Into Practice (Vol. 16, Issue 2, pp. 53-59). Taylor \& Francis Group . https://doi.org/10.1080/00405847709542675

Korsgaard, M. A., Brower, H. H., \& Lester, S. W. (2015). It Isn't Always Mutual. Journal of Management, 41(1), 47-70. https://doi.org/10.1177/0149206314547521

Kramer, R. M. (Roderick M., \& Tyler, T. R. (1996). Trust in organizations : frontiers of theory and research. Sage Publications

Lilly, J., Duffy, JA., \& WIpawayangkool, K. (2016). The impact of ethical climate on organizational trust and the role of business performance: if business performance increases, does ethical climate still matter? Jbam.Scholasticahq.Com. Retrieved March 17, 2019, from https://jbam.scholasticahq.com/article/1164.pdf

Lopez, T., \& McMillan-Capehart, A. (2009). Elements of salesperson control: an organization theory perspective. Journal of Business \& Industrial Marketing, 24(2), 98-107. https://doi.org/10.1108/08858620910931712

Mayer, R. C., \& Davis, J. H. (1999). The effect of the performance appraisal system on trust for management: A field quasi-experiment. Journal of Applied Psychology, 84(1), 123-136. https://doi.org/10.1037/0021-9010.84.1.123

Mayer, R. C., Davis, J. H., \& Schoorman, F. D. (1995). An Integrative Model Of Organizational Trust. Academy of Management Review, 20(3), 709-734. https://doi.org/10.5465/amr.1995.9508080335

Nedkovski, V., Guerci, M., De Battisti, F., \& Siletti, E. (2017). Organizational ethical climates and employee's trust in colleagues, the supervisor, and the organization. Journal of Business Research, 71, 19-26. https://doi.org/10.1016/J.JBUSRES.2016.11.004

Prottas, D. J. (2013). Relationships Among Employee Perception of Their Manager's Behavioral Integrity, Moral Distress, and Employee Attitudes and Well-Being. Journal of Business Ethics, 113(1), 51-60. https://doi.org/10.1007/s10551-012-1280-z

Rhee, K. Y. (2010). Different effects of workers' trust on work stress, perceived stress, stress reaction, and job satisfaction between Korean and Japanese workers. Safety and Health at Work, 1(1), 87-97. https://doi.org/10.5491/SHAW.2010.1.1.87

Sekaran, U., \& Bougie, R. (2016). Research methods for managers: a skill-building approach, 
Seventh

Edition,

Wiley.

https://doi.org/http://www.slideshare.net/basheerahmad/research-methods-for-business-entireebook-by-uma-sekaran

Simha, A., \& Stachowicz-Stanusch, A. (2015). The effects of ethical climates on trust in supervisor and trust in organization in a Polish context. Management Decision, 53(1), 24-39. https://doi.org/10.1108/MD-08-2013-0409

Smith, H. J., Thompson, R., \& Iacovou, C. (2009). The impact of ethical climate on project status misreporting. Journal of Business Ethics, 90(4), 577-591. https://doi.org/10.1007/s10551-009-0062-8

Sousa-Lima, M., Michel, J. W., \& Caetano, A. (2013). Clarifying the importance of trust in organizations as a component of effective work relationships. Journal of Applied Social Psychology, 43(2), 418-427. https://doi.org/10.1111/j.1559-1816.2013.01012.x

Tschannen-Moran, M., \& Hoy, W. (1998). Trust in schools: A conceptual and empirical analysis. Journal of Educational Administration, 36(4), 334-352. https://doi.org/10.1108/09578239810211518

Victor, B., \& Cullen, J. B. (1988a). The Organizational Bases of Ethical Work Climates. Administrative Science Quarterly, 33(1), 101. https://doi.org/10.2307/2392857

Victor, B., \& Cullen, J. B. (1988b). The Organizational Bases of Ethical Work Climates. Administrative Science Quarterly, 33(1), 101. https://doi.org/10.2307/2392857

Wang, Y.-D., \& Hsieh, H.-H. (2013). Organizational ethical climate, perceived organizational support, and employee silence: A cross-level investigation. Human Relations, 66(6), 783-802. https://doi.org/10.1177/0018726712460706

Whitener, E. M., Brodt, S. E., Korsgaard, M. A., \& Werner, J. M. (1998). Managers as Initiators of Trust: An Exchange Relationship Framework for Understanding Managerial Trustworthy Behavior. Academy of Management Review, 23(3), 513-530. https://doi.org/10.5465/amr.1998.926624

Wimbush, J. C., \& Shepard, J. M. (1994). Toward an understanding of ethical climate: Its relationship to ethical behavior and supervisory influence. Journal of Business Ethics, 13(8), 637-647. https://doi.org/10.1007/BF00871811

Yiu, M., \& Law, R. (2012). FACTORS INFLUENCING KNOWLEDGE SHARING BEHAVIOR: A SOCIAL-PSYCHOLOGICAL VIEW IN TOURISM. In Service Science (Vol. 3, Issue 2). http://web.csulb.edu/ rchi/ssj/papers/20122/201222.pdf

\section{Copyright Disclaimer}

Copyright for this article is retained by the author(s), with first publication rights granted to the journal.

This is an open-access article distributed under the terms and conditions of the Creative Commons Attribution license (http://creativecommons.org/licenses/by/4.0/). 